\title{
AN ANALYSIS OF MAXIM FLOUTING IN POKÉMON: DETECTIVE PIKACHU MOVIE
}

\author{
Havika Hariyani $^{1}$, Fendy Aji Setiawan ${ }^{2}$ \\ ${ }^{1}$ IKIP Siliwangi \\ ${ }^{2}$ IKIP Siliwangi \\ ${ }^{1}$ havikahariyani2709@gmail.com, ${ }^{2}$ fendyajisetiawan79@gmail.com
}

\begin{abstract}
This study aimed to analyse the use of floating maxim in the Pokémon: Detective Pikachu movie (2019), directed by Rob Letterman. The subject of the research is the conversation between the main character Tim Goodman (Justice Smith) and second character Pikachu (Ryan Reynolds). Pikachu himself is a Pokémon (pocket monster). Barely, a human can talk to a Pokémon, tough they live coexist in a harmony. However, surprisingly the main character of the movie is able to communicate to a Pokémon, though, only Pikachu-the one and only Pokémon he is able to communicate with. The theory used in this research is a theory by Grice about cooperative principle, whereas trough the theory, Grice assumes that a good communication must obey to the rule of the principle. Through the research, there are 8 cases (22.22\%) flouting maxim of quantity, 13 cases $(36.11 \%)$ flouting maxim of quality, 8 cases $(22.22 \%)$ flouting maxim of relevance and 7 cases (19.44\%) flouting maxim of manner. There are four motives found in flouting the maxim, there are competitive motive 16 cases (45.71\%). Convivial motive 4 cases (11.42\%). Collaborative motive 6 cases (17.14\%), and conflictive motive 9 cases (25.71\%).
\end{abstract}

Keywords: Maxim, Flouting maxim, Cooperative Principle

\section{INTRODUCTION}

Language is a basis essential skill that naturally obtain by every human to fulfil their needs. Language has central role on intellectual development, social, and emotional students to supported success student and learn all of lessons, Parmawati (2018). As a tool of communication, language convey the idea of the speaker and convey it into series of verbal symbols into where the recipients transmit the idea and comprehend the message. (Davis, 2014) claimed that in ordinary conversations, speakers and listeners share and obey to the principle of cooperation. This cooperation means that both speaker and listener agreed to build a proper conversation, a speaker form the speech to be understood by the recipient (listener) and in the other side, a listener is expected to provide the expected answer. Thus, it can be said that a good conversation is depends on how good the cooperation between the speaker and the listener is. This role is developed by Grice and knows as cooperative principles.

Although cooperative principles are required to build successful communication, yet sometimes a speaker may violate the maxim. It may happen unconsciously or consciously since the speaker has certain intended effect towards the conversation. (Cook, 1989) stated that there are times when some meaning derives from deliberate violation. It may happen in daily conversation because peoples used to communicate by saying anything that comes in mind, they don't think about the rules of conversational maxims or cooperative principles. Yet they only use certain strategy that called rhetorical strategies to inflect the conversation with certain motive.

In this research, the researcher enthusiastically focuses on the study of the flouting maxims as the violations of conversational maxim and Grice's cooperative principles. Thus, the researcher 
is conducted to investigate the flouting maxim in various conversation between the main character and second character of the movie. The conversation between them is interesting to analyse, because the story of the movie drives that the only person that can communicate to Pokémon is the main character, thus he ought to be keep the communication between him and Pikachu go smooth and successfully by obeying the cooperative principles. Yet, both the main character and second character kept violating the maxim consecutively. To this reason, the researcher would to analyse: (1) types of maxim flouted, (2) motive of the flouting

This study covers about kinds of flouting maxims and of conversation between the main character and second character of Pokémon: Detective Pikachu movie. Here the researcher eager to analyse the motive of the flouting maxim, the functions of the floating maxim, and the motive. There had been some research on flouting maxim, as follows:

1. The first, previous research by (Fitri \& Qodriani, 2016). In their research entitled "Floating Maxim In Tv Show: Rumpi No Secret", a journal of English Language and Literature and Study Program of IKIP Siliwangi Bandung. Their research use Griece's Cooperative principles theory. It includes kinds the four types of maxim and also discussed the floating maxims occurs on TV Shows.

2. Secondly is a research done by (Gunawan Lestari, 2019) in "An Analysis of Flouting Maxims in Conversation Speaking of The Main Character in The Movie of Home Alone 2 "Lost in New York" By John Hughes. The study discuss about the flouting maxims uses in conversation of the movie, it provides with the theory of Grice's Cooperative Principal and the reason of flouting maxims.

\section{Discourse Analysis and Pragmatic}

Discourse analysis is the analysis of language in use, it committed to an investigation of what language is used for (Brown, G \& Yule, 1983). Furthermore, pragmatic known into several terms; the study of contextual meaning, the study of how more get communicated than is said, and the study of expression of relative distance (Yule, 1996)

\section{Grice's Cooperative Principle, Maxims, and Implicature}

Grice suggested cooperative principle, as follows :

"Make your conversational contribution what is required, at the stage at which it occurs, by the accepted purpose or direction of the talk exchange in which you are engaged."(Davis, 2014).

Therefore, cooperative principle is can be concluded as an act for the speaker and the recipient to make sense on each other utterance. The aim of this principle to make the conversation to be meaningful, thus the violation to this principle may led to miss understanding in comprehending the intended meaning.

Grice also describe implicature as the capacity of speaker to make sense of the utterances although there some missing elements. That elements are often implicated and such implicatures are made possible by cooperation between speaker and listener. To this term, Thomas defined implicatory based on its original word 'imply', he stated that "To imply is to hint, suggest or convey some meaning indirectly by means of language" (Ariwangsa Rahmastra, Gede Sosiowati, \& Putra Yadnya, 2018, p. 58). Furthermore, Grice distinguishes implicatures into two main categories: Conventional implicatures, and conversational implicatures. On the last term, Grice describe maxim as the four conversational rules, as follows:

1. Maxim of quantity

Maxim of quantity demanding the participants to give the contribution an informative as required, nothing more and nothing less. 
2. Maxim of quality

Maxim of quality demanding the participants to be honest and only give truthfull information. Any respond in which there is lack adequate evidence will be flouting to maxim of quality.

3. Maxim of relation

Maxim of relation demanding the participant to reply relevantly according to the topic of communication

4. Maxim of manner: “

Maxim of manner demanding the participant of the conversation to be perspicuous, avoid obscurity, avoid ambiguity, and avoid unnecessary prolixity.

\section{Flouting Maxim}

According to Thomas (Ariwangsa Rahmastra et al., 2018, p. 65), he stated that maxim Flouting means intentionally failing to follow the maxim of cooperative principle without any intention to deceive or make a misunderstanding. The aim of this flouting is that the speaker wants the audience to understand the true meaning of the message, either literal expressed meaning or the hidden meaning. Then, the speaker assumes that the listener will be able to infer the implicit meanings of the speaker. Flouting maxim is divided into the same number of the maxims of cooperative principle by Grice's theory, therefore there are:

(1) Flouting maxim of quantity,

(2) Flouting maxim of Quality,

(3) Flouting maxim of relevance, and

(4) Flouting maxim of manners.

In terms of strategy, floating maxim can be done many various ways, Grundy (2013) as cited in (Ariwangsa Rahmastra et al., 2018) states that the rhetorical strategies which include figures of speech may be considered flouting maxims of cooperative principles. These strategies include:

(1) Tautology (expression used to express a complex meaning in an easier way.

(2) Metaphor, the use of an expression in which there is a relationship between 'metaphorical' expression and 'literal' expression (Levinson, 1983, p. 148)

(3) Overstatement, an expression where the speaker describes something stronger than the actual state of the affairs (Leech, 1983, p. 145)

(4) Understatement, the opposite of overstatement is as expression used to describes something weaker than the actual state of the affairs.

(5) Rhetorical question is a rhetorical strategy to make a question as a statement instead to get an answer (interrogative sentence). And,

(6) Irony, a figurative speech which suggest a different meaning than is said.

Leech (1983:104) also remarks that there are four reason in illocutionary functions to flouting the maxim, they are: Competitive, convivial, collaborative, and conflictive:

(1) Competitive reason relates to the illocutionary functions that competes with the social goal as in ordering, asking, demanding, and begging (Leech, 1983, p. 104).

(2) Convivial is a reason for flouting maxim where an illocutionary function coincides with the social goal as in offering, inviting, greeting, thanking, and congratulating.

(3) Collaborative reason deals when illocutionary functions is indifferent to the social goal. There are asserting, reporting announcing, and instructing.

(4) Conflictive reason is a reason where the illocutionary gaol of a conversation conflicts with social goal as in threatening, accusing, cursing, reprimanding and others (Leech, 1983, p. 104) 


\section{Synopsis of The Movie}

Harry Goodman, the best detective in Rhyme City died mysteriously. Made the cop and his only son Tim Goodman believe that Harry was died in car accident. Everyone believe that Harry was died, except Pikachu, Harry's Pokemon partner. Pikachu been all the time with Harryy and made him the only key to Harry's case, yet he got bad amnesia made him untrustable witness. By mysterious gas that Tim found at Harry's apartement made him able to speak to Pikachu. Being the only one that able to understand him, Pikachu ask Tim to reveal the mistery behind Harry's dead. So does, the thrilling adventure begin. Against various Pokemon, and even Mewtwo, the most powerfull Pokemon ever, that treathen the peacefull co-existence between human and Pokemon.

\section{METHOD}

This is descriptive qualitative research that used an observation and library research as the primary data collecting. This was done referring to both the script of the movie and film. By watching to the movie, the researcher can comprehend the context of the conversation provided by the script better. Thus, checking the script and watching the movie was done several times in order to provide accurate analysis by matching the type of flouting maxims, the reasons of flouting maxims, and the functions of the flouting maxims.

\section{RESULTS AND DISCUSSION}

\section{Results}

During make a note to the conversation between the main character (Tim Goodman) and the second character (Pikachu), researcher found that there are 57 dialogue with 32 flouting maxim. the data presented in the table below:

Table 1. Motive of Flouting Maxim

\begin{tabular}{|c|c|c|c|c|c|}
\hline No & $\begin{array}{l}\text { Flouting } \\
\text { Maxim }\end{array}$ & Motive & Quantity & Total & Percentage \\
\hline \multirow[t]{4}{*}{1} & \multirow[t]{4}{*}{ Quantity } & Competitive & 4 & \multirow[t]{4}{*}{8} & \multirow[t]{4}{*}{$22.22 \%$} \\
\hline & & Convivial & 1 & & \\
\hline & & Collaborative & 2 & & \\
\hline & & Conflictive & 1 & & \\
\hline \multirow[t]{4}{*}{2} & \multirow{4}{*}{ Quality } & Competitive & 6 & \multirow[t]{4}{*}{13} & \multirow[t]{4}{*}{36.11} \\
\hline & & Convivial & 3 & & \\
\hline & & Collaborative & 2 & & \\
\hline & & Conflictive & 1 & & \\
\hline \multirow[t]{4}{*}{3} & \multirow[t]{4}{*}{ Relevance } & Competitive & 3 & \multirow[t]{4}{*}{8} & \multirow[t]{4}{*}{22.22} \\
\hline & & Convivial & 0 & & \\
\hline & & Collaborative & 2 & & \\
\hline & & Conflictive & 3 & & \\
\hline \multirow[t]{4}{*}{4} & \multirow[t]{4}{*}{ Manner } & Competitive & 3 & \multirow[t]{4}{*}{7} & \multirow[t]{4}{*}{19.44} \\
\hline & & Convivial & 0 & & \\
\hline & & Collaborative & 0 & & \\
\hline & & Conflictive & 4 & & \\
\hline
\end{tabular}




\section{Discussion}

Types of flouting maxim used in Pokémon: Detective Pikachu movie

1. Maxim of Quantity

Example:

\begin{tabular}{lll}
\hline Pikachu & $:$ & What did you get kid? \\
\hline Tim & $:$ & I literally just met someone; she was a junior reporter at CNM. \\
& She's doing her story on Harry. I think she knows more than us. \\
\hline
\end{tabular}

In this conversation the main Character (Tim) flouted maxim of quantity because he gave to much information than required. In this movie, Pikachu is asserting some documents to find a clue to solve the case. Then suddenly Tim came in to the room, and surprised about what being happened to the room. They were ended up arguing their statement. Yet, the conversation stop when Tim suddenly found a newspaper and make a sudden silence. That's why Pikachu ask the question. Then Tim Replied; he may know someone who can help them with clue.

2. Maxim of Quality

Example:

\begin{tabular}{|c|c|}
\hline Tim & $\begin{array}{l}\text { Okay, so you're a talking Pikachu with no memory and addicted a } \\
\text { lot to caffeine. }\end{array}$ \\
\hline Pikachu & I can stop whenever I want. These are just choices \\
\hline $\begin{array}{l}\text { In this sce } \\
\text { him about } \\
\text { is, yet Pil } \\
\text { assumptio }\end{array}$ & $\begin{array}{l}\text { both Tim and Pikachu are learnt to know each order. After Pikachu told } \\
\text { at had happen to him. Tim made a general description about what Pikachu } \\
\text { u denied Tim assumption. Pikachu's statement is lie, otherwise Tim's } \\
\text { correct to mention that Pikachu is addicted a lot to caffeine. Thus, by } \\
\text { formation, Pikachu has flouted maxim of quality. }\end{array}$ \\
\hline
\end{tabular}

3. Maxim of relevance

Example:

\begin{tabular}{lll}
\hline Man & $:$ & Hey little guy, how'd you get into here? \\
\hline Pikachu & $:$ & $\begin{array}{l}\text { I know you can't understand me but put down the stapler or I'll } \\
\text { electric you }\end{array}$ \\
\hline
\end{tabular}

This is the first meeting between the main character and second character. At the beginning of the movie, both Tim and Pikachu didn't realize if they were able to communicate each other. As the setting of the movie, human can't talk to Pikachu. Because of this, the first dialogue between them occurs in irrelevant way, thus this is the flouted to maxim of relevance

4. Maxim of Manner

Example:

\begin{tabular}{l}
\hline Tim : Mr. Mime has an ability to create an invisible wall \\
\hline Pikachu $:$ Yeah I know. I've been a Pokémon too, remember? \\
\hline In this scene, Pikachu tried to make Mr. Mime to talk and to tell them the truth. Although \\
Mr. Mime is unable to talk, he communicates trough mimicry. Getting inpatient, \\
Pikachu head up and tried to strike Mr. Mime, yet he was stopped and bumped and \\
invisible wall. In this dialogue, Pikachu speaks ambiguity, because as Pokémon he may \\
instantly know other Pokémon ability, yet since he has an amnesia, he may forget it. To \\
this ambiguity Pikachu has flouted maxim of manner.
\end{tabular}


Motive behind flouting the maxim

1. Competitive motive

\begin{tabular}{l}
\hline Tim : Stop, I'm gonna throw up \\
\hline Pikachu : No, no. Kid I'm in serious trouble. I need you to listen \\
This conversation has flouting maxim of relevance embedded. Regardless Tim's \\
condition of having ill after find the fact that he is able to communicate to Pikachu. \\
Pikachu insist to demand Tim to listen and help him instead he help Tim who is having \\
a stomach-ache (Tim express that he want to throw up).
\end{tabular}

2. Convivial motive

Tim : I literally just met someone; she was a junior reporter at CNM. She's doing her story on Harry. I think she knows more than us.

Pikachu : $\quad$ The smarter ones are always do

In this dialogue, Pikachu used figurative language that flouted maxim of relevance. And the motive behind this flouting is convivial motive. It is because Pikachu actually praised for his suggestion to the case.

3. Collaborative motive

\begin{tabular}{lll}
\hline Pikachu & $:$ & We will do this. You and me \\
\hline Tim & $:$ & $\begin{array}{l}\text { I can bel.. } \\
\text { Okay, we'll meet here tomorrow morning }\end{array}$ \\
\end{tabular}

This is flouting to maxim of quantity with convivial motive. Pikachu pursued Tim to help him in a case. At first, Tim didn't want to help him, yet he suddenly changed his mind, and perhaps that is why he flouts the maxim of quantity. The expression used by time is collaborative motive, because he implies that he would help Pikachu.

4. Conflictive motive

\begin{tabular}{lll}
\hline Pikachu & $:$ & $\begin{array}{l}\text { You don't need to talk. For us I can feel what you all saying. } \\
\text { You have to be opened to the experience. Try it sometimes. }\end{array}$ \\
\hline Tim & $:$ & Yeah, I'd rather not. I already crazy talking to you \\
\hline
\end{tabular}

In this dialogue, Tim has conflictive motive when he is flouting maxim of quantity. In this scene Pikachu tried to explain that usually Pokémon and their tamer communicate via understanding trough heart to heart. Yet, rejecting Pikachu's suggesting using rude expression that may hurt Pikachu's feeling.

\section{CONCLUSION}

This study is conducted to find the types and the motive of maxims flouted in Pokémon: Detective Pikachu movie. The researcher used Grice's Theory in analysing the data. From the analysed data, the researcher found the percentage of flouting maxim of quantity is $22.22 \%$ with 8 cases. Flouting maxim of quality is $36.11 \%$ with 13 cases. Flouting maxim of relevance $22.22 \%$ with 8 cases. And flouting maxim of manner $19.44 \%$ with 7 cases.

There are four motives found in flouting the maxim, there are competitive motive 16 cases $(45,71 \%)$. Convivial motive 4 cases $(11.42 \%)$. Collaborative motive 6 cases $(17.14 \%)$, and conflictive motive 9 cases $(25.71 \%)$.

From the analysed data of the characters, the highest maxim flouting is maxim of quantity. It is because Pikachu as the second character want to convince Tim convince and to show him that 
he is trustworthy. Flouts the maxim of quality to emphasizes the audience the internal conflict within Pikachu, whereas Pikachu knows the truth of the case yet has no evidence in it since he has an amnesia. The movies flout the maxim of relevance to emphasize the characterization of Pikachu as he always often gives blunt respond to Tim. the first character, Tim, flouts maxim of manner to emphasizes his character as he accuses himself to what happen to his father that made him in appropriate manner.

\section{ACKNOWLEDGMENTS}

Alhamdulillah. Thanks to Allah swt, our Prophet Muhammad, our family and our lecturer and advisor who had support our research. We would also want to say thanks to every fellow mate who had given their opinion and support on this research.

\section{REFERENCES}

Ariwangsa Rahmastra, I. G. B., Gede Sosiowati, I. G. A., \& Putra Yadnya, I. B. (2018). The Strategies of Maxim Flouting In Lincoln Movie Script. In Humanis (Vol. 22). https://doi.org/10.24843/jh.2018.v22.i04.p15

Brown, G \& Yule, G. (1983). Teaching the spoken language. Cambridge: Cambridge University Press.

Cook, G. (1989). Discourse / Guy Cook. Oxford : Oxford University Press.

Davis, W. (2014). Implicature. Retrieved from The Stanford Encyclopedia of Philosophy website: https://plato.stanford.edu/archives/fall2014/entries/implicature/

Fitri, E., \& Qodriani, L. U. (2016). A Study on Flouting Maxims in Divergent Novel. 14(1), 3240.

Gunawan Lestari, N. (2019). An analysis of Flouting Maxims in Conversation Speaking of the Main Character in the Movie of Home Alone 2 "Lost in New York" by John Hughes. Jurnal JOEPALLT (Journal of English Pedagogy, Linguistics, Literature, and Teaching), $7(1)$.

Leech, N. G. (1983). Principle of Pragmatics. Longman. New York. 123-129.

Levinson, S. C. (1983). PRAGMATICS. Cambridge: Cambridge University Press.

Parmawati, A. (2018). The Study Correlation Between Reading Habit And Pronunciation Ability At The Second Grade Students Of Ikip Siliwangi. Eltin Journal, Journal Of English Language Teaching In Indonesia, 6(1), 46-52.

Yule, G. (1996). Pragmatics. 